\title{
The Change of Catalase Enzyme Activity in Soils by The Land Use
}

\author{
İnci Sevinç Kravkaz Kuş̧̧u ${ }^{1, a, *}$, Mustafa Ömer Karaöz ${ }^{2, b}$ \\ ${ }^{1}$ Faculty of Forestry, Kastamonu University, 37210 Kastamonu, Turkey \\ ${ }^{2}$ Department of Forestry Engineering, Faculty of Forest, Istanbul University, 34134 Istanbul, Turkey \\ *Corresponding author

A R T I C L E I N F O A B S T R A C T

\begin{tabular}{l|l}
\hline Research Article & $\begin{array}{l}\text { Analysing the factors driving the population size and activities of soil microorganisms is important } \\
\text { for understanding the soil ecosystem's structure and functioning. For this purpose, the soil enzymes } \\
\text { are used as an indicator of soil microbial activity and soil fertility. Although there are many studies } \\
\text { on the distribution and activities of various soil enzymes in soils under monoculture or crop } \\
\text { alternation conditions, there are only few studies examining the ecological relationship in natural } \\
\text { ecosystems, especially by using enzymes. In this study, it was aimed to determine the effect of } \\
\text { different land uses on the catalase enzyme activity in soil. For this purpose, the catalase enzyme } \\
\text { activities in soil samples taken from 0-5cm and 5-10cm depths in agricultural, forest, and pasture } \\
\text { Accepted : 29/05/2021 } \\
\text { lands in north and south exposures were determined and the effects of different land use, exposure, } \\
\text { and soil depth conditions on the enzyme activities were investigated. At the end of the study, it was } \\
\text { determined that the catalase enzyme activity significantly differed by the land use and the highest } \\
\text { level of catalase enzyme activity in both south and north exposures and at both depth levels was } \\
\text { found in forest soils, whereas the lowest level of activity was found in agricultural lands in north } \\
\text { exposure and pasture soils in south exposure. }\end{array}$ \\
$\begin{array}{l}\text { Keywords: } \\
\text { Enzyme } \\
\text { Catalase } \\
\text { Exposure }\end{array}$ &
\end{tabular} \\ Soil depth
}

\section{Introduction}

Since the lives of all living organisms on the earth depend directly or indirectly on the plants, the plants are defined as the most important organism group of the world (Yigit et al., 2018; Sevik, 2021). The plants fulfill various economic, ecologic, and social functions in locations, where they grow (Aricak et al., 2019; Ozel et al., 2020; Kalayci Onac et al., 2021; Cesur et al., 2021). Plants' ability to fulfill these functions depends on their healthy growth and development (Yucedag et al., 2018; Yucedag et al., 2019; Turkyilmaz et al., 2020).

As with all morphological, anatomical, and phenological characteristics of plants, plant development is driven by its genetic structure (Hrivnak et al., 2017; Imren et al., 2021) and mutual interactions between environmental conditions (Sevik et al., 2020a,b; Ertugrul et al., 2021). The environmental conditions can be classified as climatic (Cetin et al., 2018a,b; Varol et al., 2021) and edaphic (Kravkaz Kuscu et al., 2018a,b) conditions of the location, where the plant grows (Turkyilmaz et al., 2020; Cetin et al., 2020). Soil, which constitutes the edaphic ones among these conditions, is one of the most important factors influencing plant development. The soil structure and the nutrients in soil play important roles in the development of plants (Kravkaz Kuşcu and Sharaf, 2021). Thus, many studies were carried out on the relationship between plant development and soil characteristics (Zhang et al., 2020; Kravkaz Kuscu, 2020; Adekiya et al., 2020; Yucedag et al., 2021).

In assessing the functions related with fertility and soil protection in a complex soil system, it is important to consider the biological factors (Kravkaz Kuşcu and Sharaf, 2021). Being one of the most important factors influencing the soil structure and fertility, enzymes are the highmolecule catalyzers that are created by organisms but do not need an organism to function. The main responsibility of enzymes is to transform the high-molecule organic matter into simple forms, which can enter the cell and be utilized by the organism. As stated before, enzymes act as catalyzers and their presence solely ensures the faster formation of the reactions (Kravkaz Kuscu, 2014). Being one of the enzymes, catalase is an enzyme dissociating the hydrogen peroxide $\left(\mathrm{H}_{2} \mathrm{O}_{2}\right)$, which arises from metabolic 
events and respiration of living organisms and is toxic for the cell, into water and oxygen (Çengel, 2004).

It is known that enzymatic reactions are in a close relationship with soil fertility (Kravkaz Kuscu, 2019). However, the studies carried out to date remained at limited levels and there is a very scarce amount of studies carried out on forestry. In this study, it was aimed to determine the effect of different land uses on the catalase enzyme activity in soil. For this purpose, the catalase enzyme activities in soil samples taken from $0-5 \mathrm{~cm}$ and $5-10 \mathrm{~cm}$ depths in agricultural, forest, and pasture areas in north and south exposures were determined and it was aimed to reveal the effects of different land use, exposure, and soil depth on the enzyme activities.

\section{Material and Method}

\section{Material}

In this study, the forest (orman), pasture (mera), and agricultural (tarım) lands that are neighboring to each other and, consequently, have similar characteristics were determined and the areas (agriculture, pasture and forest) to take soil samples in harmony with the objective of this study were chosen in north (Figure 1) and south (Figure 2) exposures. After the preliminary examinations, the soil samples were taken from the areas in exposures mentionedabove.

At the locations, which were found to fit the purpose of the study, the soil samples were taken from 5 different points and at 2 different depth levels. Thus, 60 soil samples were taken from 2 exposures in 3 land uses (agriculture, forest, and pasture) at 2 different depth levels and with 5 repeats. While taking the samples, the pits were prepared in $80 \mathrm{~cm}$ width, $100 \mathrm{~cm}$ length, and $30 \mathrm{~cm}$ depth. The nondeteriorated soil samples with $100 \mathrm{~cm}^{3}$ volume were taken from $0-5 \mathrm{~cm}$ and $5-10 \mathrm{~cm}$ depths. Soil samples were taken in the second half of May, when the precipitation stopped but the soil kept its moisture. The samples were kept in the mobile coolers and transferred to Ankara on the same day and then, by taking the required measures, kept at $+4^{\circ} \mathrm{C}$ until the analyses.

\section{Method}

Catalase activity is an indicator of anaerobic organism activities. Catalase enzyme is secreted by many species dissociating toxic $\mathrm{H}_{2} \mathrm{O}_{2}$, which occurs during the material exchange, into water and oxygen. This procedure is performed by applying $\mathrm{H}_{2} \mathrm{O}_{2}$ into a soil buffer solution, in which the dissociating oxygen is measured using the gas volumetric method. The reaction occurs as follows;

$$
2 \mathrm{H}_{2} \mathrm{O}_{2}
$$

(manometric calculation, volume reading)

Catalase enzyme is present in all anaerobic bacteria and facultative bacteria. Bacterial catalase is an enzyme that is active between $\mathrm{pH} 3$ and 9 values. The $\mathrm{pH}$ range, in which it is active at the highest level, is 6.3-7.2, whereas the temperature range is $4-26^{\circ} \mathrm{C}$. the catalase activities of soils were determined using Beck's (1971) method that is based on the gasometric measurement of the amount of oxygen arising from the dissociation of hydrogen peroxide.

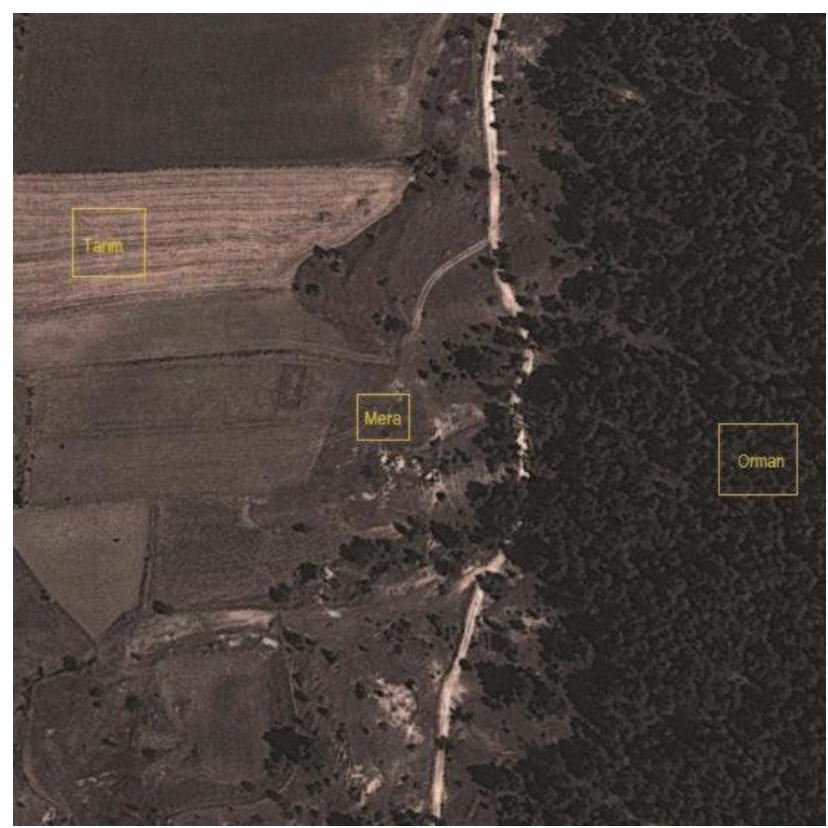

Figure 1. Sampling areas in north exposure

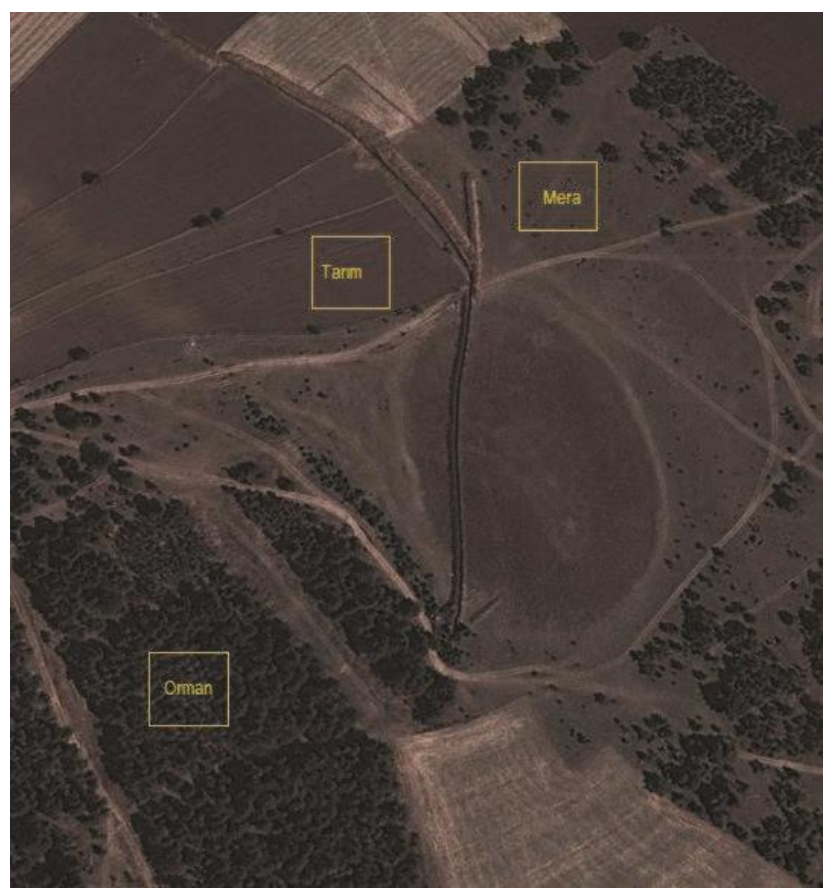

Figure 2. Sampling areas in south exposure

\section{Results and Discussion}

Identification, variance analysis and Duncan test results for catalase enzyme activities in various exposures and soil depths are presented below.

\section{Catalase Enzyme Activity of Soils in North Exposure at 0-5 cm Depth}

The identification table, the variance analysis and Duncan test results for soils at $0-5 \mathrm{~cm}$ depth with north exposure are given in Table 1, 2 and 3, respectively.

Given the identification table, it can be seen that the catalase enzyme activity in forest soils taken from $0-5 \mathrm{~cm}$ depth was 2.12 folds of the level determined in agricultural soil and 1.23 folds of the level in pasture soils. As seen in the table, the catalase enzyme activity level is approx. 1.72 folds of the level determined in agricultural soils. 
Table 1. Identification table for soils at $0-5 \mathrm{~cm}$ depth with north exposure

\begin{tabular}{|c|c|c|c|c|c|c|c|}
\hline \multirow{2}{*}{$\begin{array}{l}\text { Catalase Enzyme } \\
(\mathrm{ml} / 5 \mathrm{~g})\end{array}$} & \multirow{2}{*}{ Average } & \multirow{2}{*}{ Std.Dev. } & \multirow{2}{*}{ Std.Error } & \multicolumn{2}{|c|}{ Confidence level of $95 \%$} & \multirow{2}{*}{ Minimum } & \multirow{2}{*}{ Maximum } \\
\hline & & & & Lower Limit & Upper Limit & & \\
\hline Agriculture & 10.9286 & 1.63169 & 0.42130 & 10.0250 & 11.8322 & 8.75 & 14.59 \\
\hline Forest & 23.2002 & 12.23699 & 3.15958 & 16.4236 & 29.9768 & 8.66 & 43.38 \\
\hline Pasture & 18.7849 & 6.23128 & 1.60891 & 15.3341 & 22.2357 & 11.69 & 29.41 \\
\hline Average & 17.6379 & 9.33753 & 1.39196 & 14.8326 & 20.4432 & 8.66 & 43.38 \\
\hline
\end{tabular}

Table 2. Variance analysis results of soils at $0-5 \mathrm{~cm}$ depth with north exposure

\begin{tabular}{l|ccccc}
\hline $\begin{array}{c}\text { Catalase Enzyme } \\
(\mathrm{ml} / 5 \mathrm{~g})\end{array}$ & Sum of Squares & $\mathrm{df}$ & Mean Square & $\mathrm{F}$ & $\mathrm{P}$ \\
\hline Between Groups & 1159.043 & 2 & 579.521 & 9.091 & 0.001 \\
Within Groups & 2677.293 & 42 & 63.745 & & \\
Total & 3836.336 & 44 & & \\
\hline
\end{tabular}

Table 3. Duncan test results of soils at $0-5 \mathrm{~cm}$ depth with north exposure

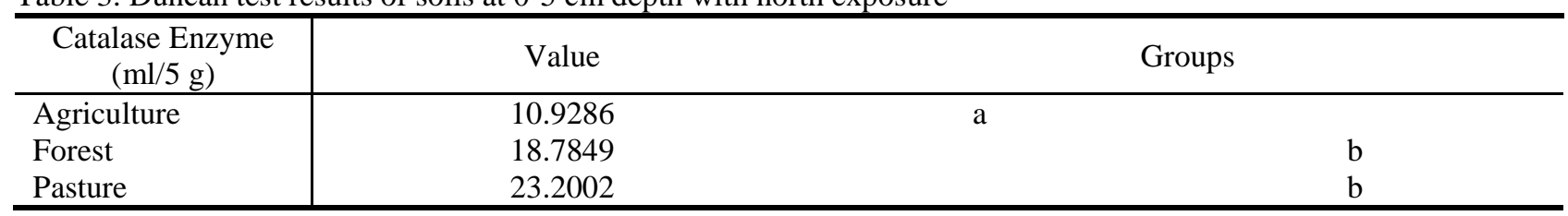

Table 4. Identification table for soils at 5-10 $\mathrm{cm}$ depth with north exposure

\begin{tabular}{l|rrrrrrr}
\hline \multirow{2}{*}{$\begin{array}{c}\text { Catalase Enzyme }(\mathrm{ml} / 5 \mathrm{~g}) \\
\text { Agriculture }\end{array}$} & \multirow{2}{*}{ Average } & \multirow{2}{*}{ Std.Dev. } & \multirow{2}{*}{ Std.Error } & \multicolumn{2}{c}{ Confidence level of 95\% } & \multirow{2}{*}{ Minimum } & \multirow{2}{*}{ Maximum } \\
\cline { 5 - 6 } Forest & 9.2823 & 2.81024 & 0.72560 & 7.7260 & 10.8386 & 4.78 & 13.61 \\
Pasture & 18.8020 & 6.05570 & 1.56357 & 15.4485 & 22.1556 & 11.85 & 30.06 \\
Average & 11.2554 & 1.89221 & 0.48857 & 10.2075 & 12.3032 & 8.20 & 13.92 \\
\hline
\end{tabular}

Table 5. Variance analysis results of soils at $5-10 \mathrm{~cm}$ depth with north exposure

\begin{tabular}{l|ccccc}
\hline $\begin{array}{c}\text { Catalase Enzyme } \\
(\mathrm{ml} / 5 \mathrm{~g})\end{array}$ & Sum of Squares & df & Mean Square & F & P \\
\hline Between Groups & 757.349 & 2 & 378.674 & 23.594 & 0.000 \\
Within Groups & 674.091 & 42 & 16.050 & & \\
Total & 1431.440 & 44 & & & \\
\hline
\end{tabular}

Table 6: Duncan test results of soils at 5-10 $\mathrm{cm}$ depth with north exposure

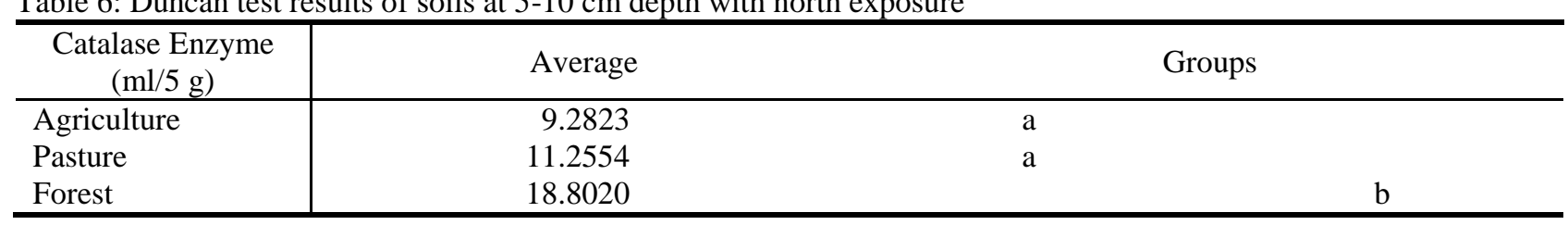

Given the variance analysis results, it was determined that the catalase enzyme activities in agricultural, forest, and pasture soils with north exposure differed significantly at the error level of 0.001 , which indicates a confidence level of $99 \%$. According to the results of the Duncan test, it can be seen that agricultural soils gathered in a group and pasture and forest soils gathered in another group. Accordingly, the pasture and forest soils taken from $0-5 \mathrm{~cm}$ depth in north exposure were found to have 1.23 folds of difference in terms of catalase enzyme activity level but the difference was found to be statistically non-significant. However, the catalase enzyme activity in agricultural soils was found to be statistically significantly (confidence level of $99 \%$ ) lower than in forest and pasture soils.

\section{Catalase Enzyme Activity of Soils in North Exposure} at 5-10 cm Depth

The identification table, the variance analysis and Duncan test results for soils at $5-10 \mathrm{~cm}$ depth with north exposure are presented in Table 4, 5 and 6, respectively.

Given the identification table, it can be seen that the catalase enzyme activity level in forest soils taken from 5$10 \mathrm{~cm}$ depth in north exposure was found to be higher than 2 folds of those found in agricultural soil samples. As seen in the table, the catalase enzyme activity in forest soils was calculated to be 1.67 folds of the catalase enzyme activity level in pasture soils. The catalase enzyme activity found in soil samples taken from pasture was approx. 1.21 folds of the level found in agricultural soil samples. Given the results of variance analysis, it was found that the catalase 
enzyme activity levels in agricultural, forest, and pasture soil samples taken from $5-10 \mathrm{~cm}$ depth in north exposure significantly differed at the confidence level of $99.9 \%$.

According to the result of the Duncan test, agricultural and pasture soil samples gathered in a group and forest soils in another group. Given these results, the catalase enzyme activity levels in forest soils taken from $5-10 \mathrm{~cm}$ depth in north exposure were higher than in agricultural and pasture soil samples.

\section{Catalase Enzyme Activity of Soils in South Exposure} at 0-5 cm Depth

The identification table, the variance analysis and Duncan test results for soils at $0-5 \mathrm{~cm}$ depth with south exposure are given in Table 7, 8 and 9, respectively.

As can be seen in the identification table, the catalase enzyme activity level found in the forest soils taken from $0-5 \mathrm{~cm}$ depth was higher than in agricultural soil samples by $41 \%$ and in pasture soil samples by $88 \%$. Besides that, the level found in agricultural soil samples was approx. $33 \%$ higher than in pasture soil samples.

According to the variance analysis results, it was determined that the catalase enzyme activities in agricultural, forest, and pasture soil samples taken from 5$10 \mathrm{~cm}$ depth in south exposure significantly varied at the confidence level of $99.9 \%$.

Given the results of the Duncan test, it can be seen that the agricultural and pasture soil samples gathered in a group and the forest soils in other group. Thus, it can be stated that the catalase enzyme activity in forest soil samples taken from $5-10 \mathrm{~cm}$ depth in south exposure was higher than in agricultural and pasture soil samples with the confidence level of 99.9.

\section{Catalase Enzyme Activity of Soils in South Exposure} at 5-10 cm Depth

The identification table, the variance analysis and Duncan test results for soils at 5-10 cm depth with south exposure are given in Table 10, 11 and 12, respectively..

As seen in the identification table, the catalase enzyme activity level found in forest soil samples taken from 5$10 \mathrm{~cm}$ depth in south exposure was approx. 2 folds of the level found in pasture soil samples. As can be seen in the table, the catalase enzyme activity found in forest soils was 1.33 folds of the level found in agricultural soil samples. Catalase activity level in agricultural soil samples was found to be 1.48 folds of the level found in pasture soil samples. Given the variance analysis results, it was found that the catalase enzyme activity levels in agricultural, forest, and pasture soil samples taken from 5-10 cm depth in south exposure significantly differed at the confidence level of $99.9 \%$.

According to the results of the Duncan test, it can be seen that each of the catalase enzyme activity levels in agricultural, forest, and pasture soil samples taken from 5$10 \mathrm{~cm}$ depth in south exposure gathered in a different group. Accordingly, the catalase enzyme activity values found in agricultural, forest, and pasture soil samples significantly differed from the others.

Table 7. Identification table for soils at $0-5 \mathrm{~cm}$ depth with south exposure

\begin{tabular}{l|ccccccc}
\hline \multirow{2}{*}{$\begin{array}{c}\text { Catalase Enzyme } \\
(\mathrm{ml} / 5 \mathrm{~g})\end{array}$} & Average & \multirow{2}{*}{ Std.Dev. } & \multirow{2}{*}{ Std.Error } & \multicolumn{2}{c}{ Confidence level of 95\% } & \multirow{2}{*}{ Minimum } & \multirow{2}{*}{ Maximum } \\
\cline { 5 - 6 } & & & Lower Limit & Upper Limit & & \\
\hline Agriculture & 20.1118 & 9.30282 & 2.40198 & 14.9601 & 25.2635 & 7.54 & 35.53 \\
Forest & 28.4405 & 9.15730 & 2.36440 & 23.3694 & 33.5117 & 14.34 & 41.35 \\
Pasture & 15.0825 & 4.48144 & 1.15710 & 12.6007 & 17.5642 & 10.39 & 22.99 \\
Average & 21.2116 & 9.57298 & 1.42706 & 18.3355 & 24.0876 & 7.54 & 41.35 \\
\hline
\end{tabular}

Table 8 . Variance analysis results of soils at $0-5 \mathrm{~cm}$ depth with south exposure

\begin{tabular}{l|ccccc}
\hline $\begin{array}{c}\text { Catalase Enzyme } \\
(\mathrm{ml} / 5 \mathrm{~g})\end{array}$ & Sum of Squares & $\mathrm{df}$ & Mean Square & $\mathrm{F}$ & $\mathrm{P}$ \\
\hline Between Groups & 1365.505 & 2 & 682.752 & 10.753 & .000 \\
Within Groups & 2666.745 & 42 & 63.494 & & \\
Total & 4032.249 & 44 & & & \\
\hline
\end{tabular}

Table 9. Duncan test results of soils at 0-5 cm depth with south exposure

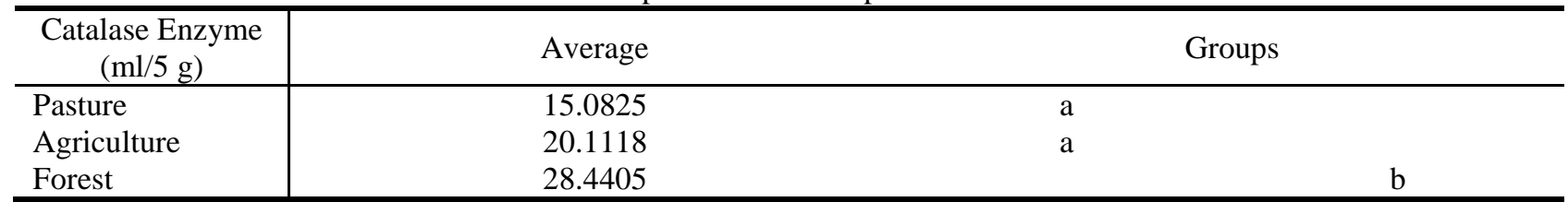

Table 10. Identification table for soils at $5-10 \mathrm{~cm}$ depth with south exposure

\begin{tabular}{l|lllllll}
\hline \multirow{2}{*}{$\begin{array}{c}\text { Catalase Enzyme } \\
(\mathrm{ml} / 5 \mathrm{~g})\end{array}$} & \multirow{2}{*}{ Average } & \multirow{2}{*}{ Std.Dev. } & \multirow{2}{*}{ Std.Error } & \multicolumn{2}{c}{ Confidence level of 95\% } & \multirow{2}{*}{ Minimum } & \multirow{2}{*}{ Maximum } \\
\cline { 5 - 6 } Agriculture & 11.9584 & 3.25764 & 0.84112 & 10.1544 & 13.7624 & 7.58 & 17.13 \\
Forest & 15.9653 & 2.52005 & 0.65067 & 14.5697 & 17.3608 & 12.33 & 21.05 \\
Pasture & 8.0782 & 2.15780 & 0.55714 & 6.8832 & 9.2731 & 4.19 & 12.35 \\
Average & 12.0006 & 4.18127 & 0.62331 & 10.7444 & 13.2568 & 4.19 & 21.05 \\
\hline
\end{tabular}


Table 11. Variance analysis results of soils at $5-10 \mathrm{~cm}$ depth with south exposure

\begin{tabular}{l|ccccc}
\hline $\begin{array}{c}\text { Catalase Enzyme } \\
(\mathrm{ml} / 5 \mathrm{~g})\end{array}$ & Sum of Squares & $\mathrm{df}$ & Mean Square & $\mathrm{F}$ & $\mathrm{P}$ \\
\hline Between Groups & 0.023 & 2 & 0.012 & 20.710 & .000 \\
Within Groups & 0.024 & 42 & 0.001 & & \\
Total & 0.047 & 44 & & & \\
\hline
\end{tabular}

Table 12. Duncan test results of soils at $5-10 \mathrm{~cm}$ depth with south exposure

\begin{tabular}{|c|c|c|c|}
\hline $\begin{array}{l}\text { Catalase Enzyme } \\
(\mathrm{ml} / 5 \mathrm{~g})\end{array}$ & Average & & Groups \\
\hline $\begin{array}{l}\text { Pasture } \\
\text { Agriculture } \\
\text { Forest }\end{array}$ & $\begin{array}{c}8.0782 \\
11.9584 \\
15.9653\end{array}$ & $\mathrm{a}$ & $\mathrm{b}$ \\
\hline
\end{tabular}

\section{Conclusion}

As a result of the present study, it was determined that the catalase enzyme activity levels significantly varied by the land use in both south and north exposures and at both depth levels. According to the results obtained from the variance analysis and Duncan test, the highest catalase enzyme activity level in both south and north exposures and at both depth levels was found in soil samples taken from the forest, whereas the lowest values were obtained in agricultural soil samples for north exposure and pasture soil samples for south exposure.

The results obtained from the present study are generally in corroboration with the related literature. Wang et al. (2012) reported that the highest level of catalase enzyme activity in areas covered with Robinia pseudoacacia and Platycladus orientalis and the lowest catalase enzyme activity level in the agricultural areas.

Li et al. (2014) compared the forestation area, natural forest, bush, terrace, deserting rock area, and agricultural areas in terms of catalase enzyme activity level and reported the lowest catalase enzyme activity level in natural forest areas and there was no statistically significant difference between these areas.

Kravkaz Kuşcu (2019) reported that catalase enzyme activity level varied depending on the plant species in soils, where different plant species are grown under different shadow conditions, and that the highest catalase enzyme activity level was found in open areas for Betula pendula and the lowest catalase enzyme activity level was found in open area for Gleditsia triacanthos. Rodriguez and Truelove (1982) determined that the soil catalase activity level varied depending on the plant species and that the highest level of catalase enzyme activity was found with wheat, soybean, and common vetch, whereas the lower levels were reported for corn and cotton parcels.

It was reported that the catalase enzyme activity decreased in irrigated soils (Okur et al., 2001). Formanek and Vranova (2003) showed that the catalase enzyme activity varied depending on the plant cover and was related with the amount of organic substances, total $\mathrm{N}$, available $\mathrm{P}$ and $\mathrm{K}$.

On the other hand, Kizilkaya et al. (1998) asserted that there was no relationship between catalase enzyme activity and organic substance.

Türkmen et al. (2013) stated that the catalase enzyme activity decreased with increasing depth and the highest catalase enzyme activity levels were observed in unprocessed soils. This finding corroborates with the results obtained in the present study.

Plant development is shaped by the plant's genetic structure (Hrivnak et al., 2017) and environmental conditions (Sevik et al., 2019a,b; Turkyilmaz et al., 2019). The environmental conditions influencing the plant development are also related with each other. For instance, sunlight influences the development, form, and morphological and anatomic characteristics of plant (Sevik et al., 2017; Yigit et al., 2018) and it also increases the temperature. The temperature affects the moisture level of soil and moisture influences the microbial activities and enzymatic activities (Kravkaz Kuscu, 2014; Szymańska et al., 2017; Yang et al., 2018; Yigit et al., 2019; Ertugrul et al., 2019). Thus, there are many environmental factors interacting with each other and influencing the soil structure and, consequently, the plant development (Ozkazanc et al., 2019; Aricak et al., 2020; Ozel et al., 2021; Koc, 2021). The climatic factors such as precipitation, temperature, and light (Kilicoglu et al., 2020; Sevik et al., 2021), the edaphic factors such as soil $\mathrm{pH}$, amount of organic matters, and depth (Kravkaz Kuscu et al., 2019; Varol et al., 2019), the factors causing stress such as drought (Topacoglu et al., 2016; Mahmood et al., 2020), frost (Sevik and Karaca, 2016; Joshi et al., 2020), pollution (Mutlu et al., 2016; Mutlu and Aydın Uncumusaoglu, 2016; Mutlu and Kurnaz, 2017; Mutlu and Aydın Uncumusaoglu, 2017; Aydın Uncumusaoglu and Mutlu, 2017; Mutlu and Kurnaz, 2018; Turkyilmaz et al., 2018; Kükrer and Mutlu, 2019; Mutlu, 2019; Ucun Ozel et al., 2020; Emin et al., 2020; Kutlu and Mutlu, 2021; Tokatli et al., 2021), and human-origin factors such as fertilization (Moncada et al., 2021; Soumare et al., 2021), irrigation (Shu et al., 2020; Parkash et al., 2021), and hormone implementations (Guney et al., 2016a,b; Yucedag et al., 2019; Ashokhan et al., 2020) significantly affect each other, plant development, and soil structure. In conclusion, in order to determine the effects of enzyme activities on soil fertility and plant development and to use them purposefully, it is necessary to increase and diversify the future studies to be carried out on this subject.

\section{References}

Adekiya AO, Agbede T M, Olayanju A, Ejue WS, Adekanye TA, Adenusi TT, Ayeni JF. 2020. Effect of biochar on soil properties, soil loss, and cocoyam yield on a tropical sandy loam Alfisol. The Scientific World Journal. 
Aricak B, Cetin M, Erdem R, Sevik H, Cometen H. 2019. The change of some heavy metal concentrations in Scotch pine (Pinus sylvestris) depending on traffic density, organelle and washing. Applied Ecology and Environmental Research, 17(3): 6723-6734.

Aricak B, Cetin M, Erdem R, Sevik H, Cometen H. 2020. The Usability of Scotch Pine (Pinus sylvestris) as a Biomonitor for Traffic-Originated Heavy Metal Concentrations in Turkey. Polish Journal of Environmental Studies, 29:2. doi: 10.15244/pjoes/109244

Ashokhan S, Othman R, Abd Rahim MH, Karsani SA, Yaacob JS. 2020. Effect of plant growth regulators on coloured callus formation and accumulation of azadirachtin, an essential biopesticide in Azadirachta indica. Plants, 9(3):352.

Beck TH. 1971. The determination of catalase activity in soils. Journal of Plant Nutritional Soil Science, 130:68-81.

Çengel M. 2004. Toprak Mikrobiyolojisi. Ege Üniversitesi Ziraat Fakültesi Yayınları, 558: pp. 19-25, İzmir

Çetin M, Sevik H, Cobanoglu O. 2020. Ca, Cu, and Li in washed and unwashed specimens of needles, bark, and branches of the blue spruce (Picea pungens) in the city of Ankara. Environmental Science and Pollution Research, 1-10.

Cetin M, Sevik H, Yigit N, Ozel HB, Aricak B, Varol T. 2018a. The variable of leaf micromorphogical characters on grown in distinct climate conditions in some landscape plants. Fresenius Environmental Bulletin, 27(5): 3206-3211.

Cetin M, Sevik H, Yigit N. 2018b. Climate type-related changes in the leaf micromorphological characters of certain landscape plants. Environmental monitoring and Assessment, 190:7-404.

Emin N, Mutlu E, Güzel AE. 2020. Determination the effectiveness of the cytotoxic analysis on the water quality assessments. Turkish Journal of Agriculture-Food Science and Technology, 8(2):478-483.

Ertugrul M, Ozel HB, Varol T, Cetin M, Sevik H. 2019. Investigation of the relationship between burned areas and climate factors in large forest fires in the Çanakkale region. Environmental Monitoring and Assessment, 191(12):737.

Ertugrul M, Varol T, Ozel HB, Cetin M, Sevik H. 2021. Influence of climatic factor of changes in forest fire danger and fire season length in Turkey. Environmental Monitoring and Assessment, 193(1):1-17.

Formánek P, Vranová V. 2003. The effect of spruce stand thinning on biological activity in soil. Journal of Forest Sc1ence, 49 (11): 523-530.

Guney K, Cetin M, Sevik H, Guney KB. 2016a. Influence of germination percentage and morphological properties of some hormones practice on Lilium martagon L. Seeds. Oxidation Communications, 39(1-II): 466-474

Guney K, Cetin M, Sevik H, Guney KB. 2016b. Effects of some hormone applications on germination and morphological characters of endangered plant species Lilium artvinense $\mathrm{L}$. Seeds, New Challenges in Seed Biology-Basic and Translational Research Driving Seed Technology, Dr. Susana Araújo. InTech, (4): pp. 97-112.

Hrivnák M, Paule L, Krajmerová D, Kulaç Ş, Şevik H, Turna İ, Tvauri I, Gömöry D. 2017. Genetic variation in Tertiary relics: The case of eastern-Mediterranean Abies (Pinaceae). Ecology and Evolution, 7(23):10018-10030. (Pinaceae). Ecology and evolution, 7 (23), 10018-10030.

Imren E, Kurt R, Yucedag C, Bilir N, Ozel HB, Cetin M, Sevik H. 2021. Selection of superior clones by the multidimensional decision making techniques in scots pine seed orchard, Journal of Forests, 8(1): 13-22.

Joshi NC, Yadav D, Ratner K, Kamara I, Aviv-Sharon E, Irihimovitch V, Charuvi D. 2020. Sodium hydrosulfide priming improves the response of photosynthesis to overnight frost and day high light in avocado (Persea americana Mill, cv.'Hass'). Physiologia Plantarum, 168(2): 394-405.
Kilicoglu C, Cetin M, Aricak B, Sevik H. 2020. Site selection by using the multi-criteria technique-a case study of Bafra, Turkey. Environmental Monitoring and Assessment. DOI: 10.1007/s10661-020-08562-1

Kızılkaya R, Arcak S, Horuz A, Karaca A. 1998. Çeltik tarımı yapilan toprakların enzim aktiviteleri üzerine toprak özelliklerinin etkisi. Pamukkale Üniversitesi Mühendislik Fakültesi, Mühendislik Bilimleri Dergisi, 4(3):797-804.

Koc I. 2021. Using Cedrus atlantica's annual rings as a biomonitor in observing the changes of $\mathrm{Ni}$ and $\mathrm{Co}$ concentrations in the atmosphere, Environmental Science and Pollution Research. DOI:10.1007/s11356-021-13272-3 Research.

Kravkaz Kuscu IS, Cetin M, Yigit N, Savaci G, Sevik H. 2018a. Relationship between enzyme activity (urease-catalase) and nutrient element in soil use. Polish Journal of Environmental Studies, 27(5): 2107-2112.

Kravkaz Kuscu IS. 2014. Comparison of enzymes activities in Agricultural-Range-Forest soils in Kastamonu region. Doctoral Thesis, Istanbul University, Graduate school of Natural and Applied Sciences, Depaertment of Forestry Engineering, Soil Science and Ecology, Istanbul.

Kravkaz Kuscu IS. 2019. Changing of soil properties and ureasecatalase enzyme activity depending on plant type and shading. Environmental Monitoring and Assessment, 191(3):1-8.

Kravkaz Kuscu IS. 2020. Certain soil characteristics and light conditions of enzyme activities and variance conditional to plant type. Environmental Monitoring and Assessment, 192(4): 1-9.

Kravkaz-Kuscu IS, Sariyildiz T, Cetin M, Yigit N, Sevik H, Savaci G. 2018b. Evaluation of the soil properties and primary forest tree species in Taşköprü (Kastamonu) district. Fresenius Environmental Bulletin, 27(3):1613-1617.

Li Q, Liang JH, He YY, Hu QJ, Yu S. 2014. Effect of land use on soil enzyme activities at karst area in Nanchuan, Chongqing, Southwest China, Plant Soil Environment, 60(1): 15-20.

Mahmood T, Khalid S, Abdullah M, Ahmed Z, Shah MKN, Ghafoor A, Du X. 2020. Insights into drought stress signaling in plants and the molecular genetic basis of cotton drought tolerance. Cells, 9 (1):105.

Moncada A, Miceli A, Vetrano F. 2021. Use of plant growthpromoting rhizobacteria (PGPR) and organic fertilization for soilless cultivation of basil. Scientia Horticulturae, 275:109733.

Mutlu E. 2019. Evaluation of spatio-temporal variations in water quality of Zerveli stream (northern Turkey) based on water quality index and multivariate statistical analyses. Environmental Monitoring and Assessment, 191(6): 1-14.

Mutlu E, Emin Güzel A. 2019. Evaluation of Some Physicochemical Water Quality Parameters of Gümüşsuyu Pond (Sinop-Erfelek), Turkish Journal of Agriculture-Food Science and Technology 7(sp3); 72-77

Okur N, Çengel M, Uçkan H, Katkat V. 2001. Kirlenme sürecindeki İznik göl suyu ile sulanan tarım topraklarında mikrobiyolojik aktivitenin değişimi. Ege Üniversitesi Ziraat Fakültesi Dergisi, 38(2-3):119-126.

Ozel HB, Cetin M, Sevik H, Varol T, Isik B, Yaman B. 2021. The effects of base station as an electromagnetic radiation source on flower and cone yield and germination percentage in Pinus brutia Ten. Biologia Futura. DOI: https://doi.org/10.1007/ s42977-021-00085-1

Ozel HB, Donduran B, Cakmakli E, Sevik H. 2020. Factors affecting success in natural regeneration works of cedar (Cedrus libani A. Rich.) In Kas region of Antalya. World Journal of Advanced Research and Reviews, 6(2):054-059. Doi: https://doi.org/10.30574/wjarr.2020.6.2.0127 
Ozkazanc NK, Ozay E, Ozel HB, Cetin M, Sevik H. 2019. The habitat, ecological ife conditions, and usage characteristics of the otter (Lutra lutra L. 1758) in the Balikdami Wildlife Development Area. Environmental Monitoring and Assessment, 191(11): 645.

Parkash V, Singh S, Deb SK, Ritchie GL, Wallace RW. 2021. Effect of deficit irrigation on physiology, plant growth, and fruit yield of cucumber cultivars. Plant Stress, 1:100004.

Rodriguez R, Truelove B. 1982. Effects of crop rotation and fertilization on catalase activity in a soil of the Sounth-Eastern U.S.A, 97-104

Sevik H, Cetin M, Kapucu O, Aricak B, Canturk U. 2017. Effects of light on morphologic and stomatal characteristics of Turkish Fir needles (Abies nordmanniana subsp. Bornmulleriana Mattf.). Fresenius Environmental Bulletin, 26 (11):6579-6587.

Sevik H, Cetin M, Ozel HB, Akarsu H, Cetin IZ. 2020b. Analyzing of usability of tree-rings as biomonitors for monitoring heavy metal accumulation in the atmosphere in urban area: a case study of cedar tree (Cedrus sp.). Environmental Monitoring and Assessment, 192(1):23. doi: https://doi.org/10.1007/s10661-019-8010-2 Assessment

Sevik H, Cetin M, Ozel HB, Erbek A, Cetin IZ. 2020a. The effect of climate on leaf micromorphological characteristics in some broad-leaved species. Environment, Development and Sustainability, 1-13.

Sevik H, Cetin M, Ozturk A, Yigit N, Karakus O. 2019a. Changes in micromorphological characters of Platanus orientalis L. leaves in Turkey. Applied Ecology and Environmental Research, 17(3): 5909-5921. DOI:http://dx.doi.org/10.15666/ aeer/1703_59095921

Sevik H, Cetin M, Yigit N, Aricak B, Ozturk S, Onac AK, Kuscu ISK. 2021. The effect of shadow conditions on stomatal characters of several plants used in landscape design. World Journal of Advanced Research and Reviews, 9(3):109-115.

Sevik H, Karaca U. 2016. Determining the resistances of some plant species to frost stress through ion leakage method. Febfresenius Environmental Bulletin, 25(8): 2745-2750.

Sevik H, Ozel HB, Cetin M, Özel HU, Erdem T. 2019b. Determination of changes in heavy metal accumulation depending on plant species, plant organism, and traffic density in some landscape plants. Air Quality, Atmosphere \& Health, 12 (2): 189-195.

Sevik H, Ozel HB. 2021. The usability of Cupressus arizonica annual rings in monitoring the changes in heavy metal concentration in air. Environmental Science and Pollution Research, DOI: 10.1007/s11356-021-13166-4; https://doi.org/ 10.1007/s11356-021-13166-4

Sevik H. 2021. The Variation of Chrome Consantration in Some Landscape Plants Due to Species, Organ and Traffic Density. Turkish Journal of Agriculture-Food Science and Technology, 9(3): 595-600.

Shu LZ, Liu R, Min W, Wang YS, Hong-mei Y, Zhu PF, Zhu JR. 2020. Regulation of soil water threshold on tomato plant growth and fruit quality under alternate partial root-zone drip irrigation. Agricultural Water Management, 238:106200.

Soumare A, Boubekri K, Lyamlouli K, Hafidi M, Ouhdouch Y, Kouisni L. 2021. Efficacy of phosphate solubilizing Actinobacteria to improve rock phosphate agronomic effectiveness and plant growth promotion. Rhizosphere, $17,: 100284$.
Szymańska R, Ślesak I, Orzechowska A, Kruk J. 2017. Physiological and biochemical responses to high light and temperature stress in plants. Environmental and Experimental Botany, 139:165-177.

Topacoglu O, Sevik H, Akkuzu E. 2016. Effects of water stress on germination of Pinus nigra Arnold. Seeds. Pakistan Journal of Botany, 48(2): 447-453.

Türkmen C, Müftüoğlu NM, Kavdır Y. 2013. Değișik yöntemlerle 1slah edilen meralarda bazı toprak kalite özelliklerinin değişimi. Tarım Bilimleri Dergisi, 19:245-255.

Turkyilmaz A, Cetin M, Sevik H, Isinkaralar K, Saleh EAA. 2020. Variation of heavy metal accumulation in certain landscaping plants due to traffic density. Environment, Development and Sustainability, 22(3): 2385-2398.

Turkyilmaz A, Sevik H, Cetin M, Ahmaida Saleh EA. 2018. Changes in heavy metal accumulation depending on traffic density in some landscape plants. Polish Journal of Environmental Studies, 27(5): 2277-2284.

Turkyilmaz A, Sevik H, Isinkaralar K, Cetin M. 2019. Use of tree rings as a bioindicator to observe atmospheric heavy metal deposition. Environmental Science and Pollution Research, 26 (5):5122-5130.

Ucun Ozel H, Gemici BT, Gemici E, Ozel HB, Cetin M, Sevik H. 2020. Application of artificial neural networks to predict the heavy metal contamination in the Bartin River. Environmental Science and Pollution Research, 1-18.

Varol T, Canturk U, Cetin M, Ozel HB, Sevik H. 2021. Impacts of climate change scenarios on European ash tree (Fraxinus excelsior L.) in Turkey. Forest Ecology and Management. Forest Ecology and Management 491:119199. DOI: 10.1016/j.foreco.2021.119199

Varol T, Ertuğrul M, Özel HB, Emir T, Çetin M. 2019. The effects of rill erosion on unpaved forest road. Applied Ecology and Environmental Research, 17(1):825-839.u.

Wang B., Liu G., Xue S. 2012. Effect of Black Locust (Robinia pseudoacacia) on Soil Chemical And Microbiological Properties in The Eroded Hilly Area of China's Loess Plateau. Environmental Earth Science 65:597-607, DOI:10.1007/s12665-011-1107-8.

Yang L, Wen KS, Ruan X, Zhao YX, Wei F, Wang Q. 2018. Response of plant secondary metabolites to environmental factors. Molecules, 23(4): 762.

Yigit N, Cetin M, Ozturk A, Sevik H, Cetin S. 2019. Varitation of stomatal characteristics in broad leaved species based on habitat. Applied Ecology and Environmental Research 17(6):12859-12868.

Yiğit N, Çetin M, Şevik H. 2018. The change in some leaf micromorphological characters of Prunus laurocerasus L. species by their habitat. Turkish Journal of Agriculture-Food Science and Technology, 6(11): 1517-1521. DOI: https://doi.org/10.24925/turjaf.v6i11.1517-1521

Yigit N, Öztürk A, Sevik H. 2014. Ecological impact of urban forests (Example of Kastamonu urban forest). International Journal of Engineering Sciences \& Research Technology. 3(12): 558-562.

Yucedag C, Ozel HB, Cetin M, Sevik H. 2019. Variability in morphological traits of seedlings from five Euonymus japonicus cultivars. Environmental monitoring and Assessment, 191(5): 1-4

Zhang C, Li X, Yan H, Ullah I, Zuo Z, Li L, Yu J. 2020. Effects of irrigation quantity and biochar on soil physical properties, growth characteristics, yield and quality of greenhouse tomato. Agricultural Water Management, 241: 106263. 